\title{
QUIZIZZ AS INTERACTIVE AND GAMIFIED ASSESSMENT PLATFORM: VOICES FORM INDONESIAN EFL SECONDARY LEARNERS
}

\author{
Moh. Ilham Dzikrullah \\ STKIP Al Hikmah Surabaya, Surabaya, Indonesia \\ E-mail:drik.urlloh44@gmail.com \\ Ahmad Syafi'i \\ STKIP Al Hikmah Surabaya, Surabaya, Indonesia \\ E-mail:ahmadsyafii20@gmail.com
}

\begin{abstract}
@๑ఠ
(C)2021 by the authors. Submitted for possible open access publication under the terms and conditions of the Creative Commons Attribution (CC-BY-SA) license (https://creativecommons.org/licenses/by-sa/4.0/) doi) DOI: http://dx.doi.org/10.30983/educative.4916
\end{abstract}

\begin{tabular}{l|l|l} 
Submission: October 30, 2021 & Revised : November 20, 2021 & Published: December 31, 2021
\end{tabular}

\begin{abstract}
Almost every aspect of human life on earth has been disrupted since the emergence of Covid-19, particularly education. Many countries have decided to close schools and universities. This condition has forced the Indonesian government through its Ministry of Education to implement policies that move conventional classrooms to online classrooms. This process is carried out to maintain the health of students. The learning process has been aided by the use one of applications available on the internet called Student Response System (SRS). This study investigates secondary school students' perceptions towards the implementation of Quizizz as an assessment platform in teaching English. Mixed-method research has been implemented in this study. The study involved 61 students as the participants in the quantitative stage and six students in the qualitative stage. The main instruments employed in this research are an online questionnaire and in-depth interview. The findings indicated that the students have both positive and negative perceptions toward the use of online assessment, especially Quizizz. The students enjoyed Quizizz and thought it was exciting, interesting, motivating, and enjoyable because it was distinct from other platforms. Quizizz had an interactive display, which made it simple for students to use. However, in addition to the positive perception of Quizizz as an assessment platform in English teaching, some students expressed a negative perception of Quizizz as an assessment tool. According to the data, one of the platform's negative perceptions was the presence of music.
\end{abstract}

Keywords: student's perception, online assessment, quizizz

Abstrak

Hampir setiap aspek kehidupan manusia di muka bumi ini terganggu sejak. munculnya Covid-19, khususnya pendidikan. Banyak negara telah memutuskan untuk menutup sekolah dan universitas. Kondisi ini memaksa pemerintah Indonesia melalui Kementerian Pendidikan untuk menerapkan kebijakan pemindahan ruang kelas konvensional menjadi ruang kelas daring. Proses ini dilakukan untuk menjaga kesehatan siswa agar terbindar dari Covid-19. Proses pembelajaran dapat dibantu dengan menggunakan salah satu aplikasi di internet yang bernama Student Response System (SRS). Menurut pernyataan tersebut, peneliti menyelidiki persepsi siswa sekolah menengab terbadap penerapan Quizizz. sebagai platform penilaian dalam pengajaran bahasa Inggris. Penelitian metode campuran telah diterapkan dalam penelitian ini. Penelitian ini melibatkan 61 siswa sebagai partisipan pada tahap kuantitatif dan 6 siswa pada tahap kualitatif. Instrumen utama yang digunakan dalam penelitian ini adalab kuesioner online dan wawancara mendalam. Temuan menunjukkan bahwa siswa memiliki persepsi positif dan negatif terbadap penggunaan penilaian online, terutama di Quiziz:. Para siswa menikmati Quizizz dan menganggapnya menyenangkan, menarik, memotivasi, dan menyenangkan karena platform Quizizz berbeda dari yang lain. Quizizz memiliki tampilan interaktif, yang memudabkan siswa dalam menggunakan platform. Namun, selain persepsi positif tentang Quizizz sebagai platform penilaian dalam pengajaran bahasa Inggris, beberapa siswa menyatakan persepsi negatif tentang Quirizz sebagai penilaian. Menurut data, salah satu persepsi negatif platform adalah kehadiran musik.

Kata Kunci: persepsi siswa, penilaian online, Quizziz. 


\section{Introduction}

The Indonesian government has taken appropriate measures to closely track the COVID-19 outbreak worldwide by the World Health Organization (WHO). The virus was first detected in Wuhan, South China in November 2019 and then spread across the globe. The COVID-19 pandemic is a disaster that has affected the global population.

Because of this, many countries, including Indonesia, have decided to close schools and universities. This situation has compelled the Indonesian government to implement policies that shift traditional classrooms to online classrooms.

Online learning is becoming increasingly popular. This procedure is carried out to keep students healthy and avoid Covid19. Through the use of the internet, students can learn anywhere and at any time. It means that learning is more accessible during the Covid-19 pandemic.

During a pandemic, the education world in Indonesia must follow policies that aid the school conditions in such an emergency. Schools must be compelled into implementing e-learning ${ }^{1}$. This is in line with research conducted by M. Ozden, Ismail Erturk, and Refik Sanli ${ }^{2}$ that clarified how computer-assisted evaluation can refer to any type of computer use in the process of determining individual's expertise, skills, and abilities. Because of the availability of computer-based assessment, teachers can easily set up online quizzes or other items related to student evaluations.

One of the internet-based applications that can help with the learning process is

1 Rizqon H Syah, 'Dampak Covid-19 Pada Pendidikan Di Indonesia: Sekolah, Keterampilan, Dan Proses Pembelajaran', SALAM: Jurnal Sosial Dan Budaya Syar-I, 7.5

$<$ https://doi.org/10.15408/sjsbs.v7i5.15314>.

2 M. Ozden, Ismail Erturk, and Refik Sanli, 'Students' Perceptions of Online Assessment: A Case Study.', International Journal of E-Learning \& Distance Education, 19.2 (2004), 77-92. known as the Student Response System (SRS). This is a classroom technology that allows students to answer questions using their phone or wireless device from their seat or location ${ }^{3}$.

SRS, or Student Response System, can be used to perform learning outside of the classroom. The SRS can help a teacher deliver assessments, assign homework, and perform other tasks. In addition, if an instructor is unable to teach in the classroom, SRS can still complete the assessment process. Clickers can be used by teachers to make certain aspects of the teaching or assessment process available to students.

The SRS creates a unified environment for learning and assessing activities. These frameworks enable educational institutions to deal with an increasing number of online or hybrid courses (partly online, partly face-toface) by utilizing a common interface and set of resources ${ }^{4}$. For several years, Quizizz, Kahoot, Duolingo, and other assessment platform have been widely used to assist teachers.

Among those aforementioned assessment platforms, Quizizz has become the most widely used assessment platform in schools. It is an interactive software that makes learning fun. As a result, Quizizz is one of many fantastic tools for organizing class quizzes. This application is a fun multiplayer game platform that allows students to control the pace of their classroom activity ${ }^{5}$. This is consistent with research conducted by Pepen

3 Jeryl D. Benson, Kimberly A. Szucs, and Meredith Taylor, 'Student Response Systems and Learning: Perceptions of the Student', Occupational Therapy in Health Care, 30.4 (2016), 406-14 <https://doi.org/10.1080/07380577.2016.1222644>.

4 Yefim Kats, Learning Management System Technologies and Software Solutions for Online Teaching: Tools and Applications, Learning Management System Technologies and Software Solutions for Online Teaching: Tools and Applications, 2010 <https://doi.org/10.4018/978-161520-853-1>.

${ }^{5}$ Yudi Basuki and Yeni Hidayati, 'Kahoot! Or Quizizz: The Students' Perspectives', January, 2019 <https://doi.org/10.4108/eai.27-4-2019.2285331>. 
Permana and Irma Permatawati ${ }^{6}$, who stated that Quizizz is a game-based online testing tool that allows for fun classroom activities.

Numerous studies have been undertaken to investigate the effectiveness of Quizziz as an effective and enjoyable learning assessment platform. It is consistently used as integrated learning evaluation media ${ }^{7}$, an effective alternative medium for teaching a specific subject ${ }^{8}$, an alternative media for improving certain skills in English ${ }^{9}{ }^{10}$, a fun and motivating platform with an attracting delivery ${ }^{11}$ that improves students' attentions ${ }^{12}$ and increases their motivation ${ }^{1314}$. The program

${ }^{6}$ Pepen Permana and Irma Permatawati, 'Using Quizizz as a Formative Assessment Tool in German Classrooms', 424.Icollite 2019 (2020), 155-59 <https://doi.org/10.2991/assehr.k.200325.073>.

${ }^{7}$ Nelius Harefa, Marudut Sinaga, and Saronom Silaban, 'Students Perception and Interest on Chemistry: Learning Evaluation Integrated Quizziz Media', Jurnal Pendidikan Kimia, 12.3 (2020), 143-50 $<$ https://doi.org/10.24114/jpkim.v12i3.21163>.

8 Emily A. Nojen, "The Effectiveness Of Interactive Learning Based On Quizziz Applications Among Students Of Tourism And Hospitality Marketing', Jurnal Asian Pendidikan, 1 (2021), 22-27.

${ }^{9}$ Diah Ayu Manik Pradnyadewi and Putu Enik Kristiani, 'Use of Quizizz In Improving Students' Reading Skill', The Art of Teaching English as a Foreign Language, $\quad 1.2 \quad$ (2021), 1-7 <https://doi.org/10.36663/tatefl.v1i2.93>.

10 Afief Fakhruddin and Eka Nurhidayat, 'Students' Perception on Quizziz As Game Based Learning in Learning Grammar in Writen Discourse', Wiralodra English Journal, 4.2 (2020), 28-38 <https://doi.org/10.31943/wej.v4i2.101>.

11 Mila Roysa and Anisa Hartani, 'Aplikasi Daring Quizziz Sebagai Solusi Pembelajaran Menyenangkan Di Masa Pandemi', Lentera: Jurnal Ilmiah Kependidikan, $\quad 13.2 \quad$ (2020), 315-26 $<$ https://doi.org/10.52217/lentera.v13i2.650>.

$12 \mathrm{R}$ Irwansyah and M Izzati, Implementing Quizizz as Game Based Learning and Assessment in the English Classroom', TEFLA Journal (Teaching English as ..., $\quad 3.1 \quad$ (2021), 13-18 $<$ https://journal.umbjm.ac.id/index.php/TEFLA/artic le/view/756>.

13 Rahmania Rahman, Erric Kondoy, and Awaluddin Hasrin, 'Penggunaan Aplikasi Quizziz Sebagai Media Pemberian Kuis Dalam Meningkatkan Motivasi Belajar Mahasiswa', JISIP (Jurnal Ilmu Sosial Dan Pendidikan), 4.3 (2020), 60-66 <https://doi.org/10.36312/jisip.v4i3.1161>.

${ }_{14}$ Cheng Kin Meng and others, 'A Gamified Classroom with Technical and Vocational Education also enhances students' academic achievement and engagement ${ }^{1516}$, fostering small group discussion ${ }^{17}$, drawing students' attention ${ }^{18}$, facilitating problem-solving skills ${ }^{19}$, encouraging positive reinforcement, incentive, and fast feedback ${ }^{20}$.

However, in this research, we are eager to investigate deeper into students' perception of Quizizz as an assessment platform in English classes, particularly during Covid-19 pandemic era.

\section{Method}

This study employs a mixed-method research. The goal of this study is to investigate the students' perception of the use of Quizziz as assessment platform in teaching English.

and Training ( TVET ) Students Using Quizziz', International Journal of Education, Islamic Studies and Social Sciences Research (IJEISR), $4.1 \quad$ (2019), 1-6 $<$ http://ijeisr.net/Journal/Vol-4-No-1-Isu-02.pdf>.

15 Derya Orhan Göksün and Gülden Gürsoy, 'Comparing Success and Engagement in Gamified Learning Experiences via Kahoot and Quizizz', Computers and Education, 135.March (2019), 15-29 <https://doi.org/10.1016/j.compedu.2019.02.015>.

${ }_{16}$ Nurfarahin Adawiah Binti Mohd Jalani and Harwati Binti Hashim, 'Quizziz: ESL Students' Perceptions in Rural School', International Journal of Scientific and Research Publications (IJSRP), 10.3 (2020), p9904 <https://doi.org/10.29322/ijsrp.10.03.2020.p9904>

17 Prema Hapsari Hidayati and others, 'Implementation of Quizziz as a Pretest and Post-Test to Evaluate the Effectiveness of Small Group Learning', 567.Icme (2021), 156-60.

18 João Batista Bottentuit Junior, 'Assessment for Learning With Mobile Apps: Exploring the Potential of Quizizz in the Educational Context', International Journal of Development Research, 10.1 (2020), 33366-71.

19 Nila Ubaidah, Imam Kusmaryono, and Anggar Titis Prayitno, 'Pendekatan Steam Berbasis Quizizz Terhadap Kemampuan Pemecahan Masalah', Konferensi Nasional Penelitian Matematika Dan Pembelajarannya(KNPMP) V, 2020, 351-62 <https://publikasiilmiah.ums.ac.id/xmlui/bitstream/ha ndle/11617/12224/ME

27. pdf? sequence $=1 \&$ is Allowed $=\mathrm{y}>$.

20 Maslawati Mohamad and others, 'Online Game-Based Formative Assessment: Distant Learners Post Graduate Students' Challenges towards Quizizz', International Journal of Scientific and Technology Research, 9.4 (2020), 994-1000 <https://doi.org/10.13140/RG.2.2.17416.75528>. 
The participants of this study were 61 students from two different classes. The entire sample $(\mathrm{N}=61)$ volunteered to participate in the quantitative stage. Six students were then purposively chosen to participate in the qualitative stage.

The main instruments employed in this research are an online questionnaire and indepth interview. The quantitative data were statistically analyzed. Qualitative data were analyzed and presented thematically. more interesting, motivating, and enjoyable. Some of the informants' expressions are as follows:

\section{Cukup menarik tapi kadang kayak buat deg degan gitu kalau ulangan. Soalnya \\ kan ada waktunya sama ada lagunya itu yang buat deg degan. (Interview/S.1)}

Furthermore, S.2 and S.3 described Quizizz as exciting, interesting, motivating, and enjoyable. Those who said Quizizz was exciting said their hearts raced at times while taking the quiz.

Iya, karena beda aja pak, soalnya tub tampilannya beda sama yang lain, jadi itu

\section{Findings and Discussion}

menurut saya yang bikin asyik

\section{Providing Exciting, Interesting,}

Motivating, and Fun Online Platform

(Interview/S.2)

All the informants agreed that Quizizz was exciting, interesting, motivating, and fun. This graph depicts the respondents' attitudes toward Quizizz.

Students find Quizizz is exciting, interesting, motivating and fun

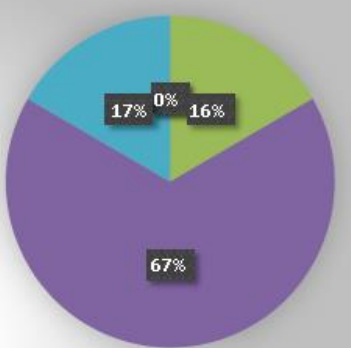

Figure 1. Students find that Quizizz is exciting, interesting, motivating, and fun

According to that figure, 17 percent of respondents strongly agreed, 67 percent agreed, 16 percent were neutral, 0 percent disagreed, and 0 percent strongly disagreed. This indicates that Quizizz was exciting, interesting, motivating, and enjoyable. According to the data, some informants agreed that they had a positive attitude toward Quizizz, describing it as exciting, interesting, motivating, and fun. Furthermore, some informants shared their thoughts on how exciting, interesting, motivating, and enjoyable Quizizz is. The majority of them agreed. Their most frequently expressed sentiment was the use of the timer in answering the questions. They realize that the Quizizz timer made answering the question

\section{Enhancing Students Eagerness to Play Quizizz}

Based on the statements of the informants, it is possible to conclude that they were all excited to play Quizizz. This diagram depicts the respondents' attitudes toward Quizziz.

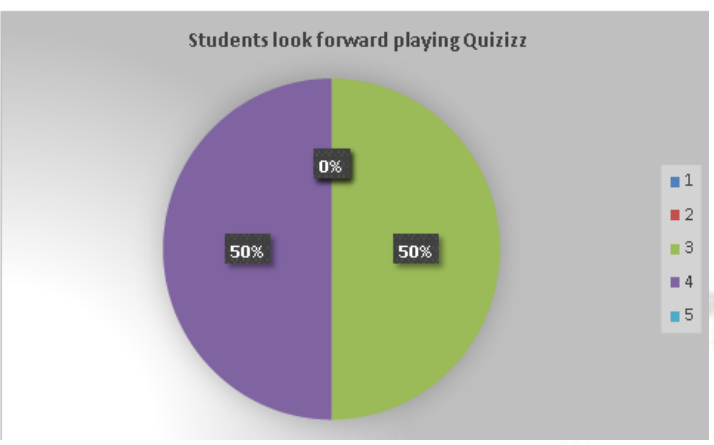

Figure 2. Students Enhancement to playing Quizizz

This figure indicated that half of those polled agreed and half were undecided. It implies that students enjoy playing Quizizz. According to the data, some of the informants agreed and looked forward to playing Quizizz.

Iya, karena kalo di Quizizz itu nanti

kita habis ngerjakan itu biasanya langsung ada pembetulan soalnya, jadi langsung enak buat kita belajar lagi (Interview/S.5)

S.2 expressed a very different viewpoint in this regard, stating that they felt bored if they continuously used Quizizz because the time available to complete the quiz was limited. That's why she chose to be neutral 
in the form given to her:

Karena kalo quiriz terus tu kayak apa ya, bosen pake lama lama. (Interview/S.2)

Furthermore, according to the data presented above, most students agreed and were enthusiastic about playing Quizizz.

\section{Fostering Students' Positive Attitude}

Based on the statements of the informants, it is possible to conclude that they were all neutral while playing Quizizz. This diagram depicts the respondents attitudes toward their opinions.

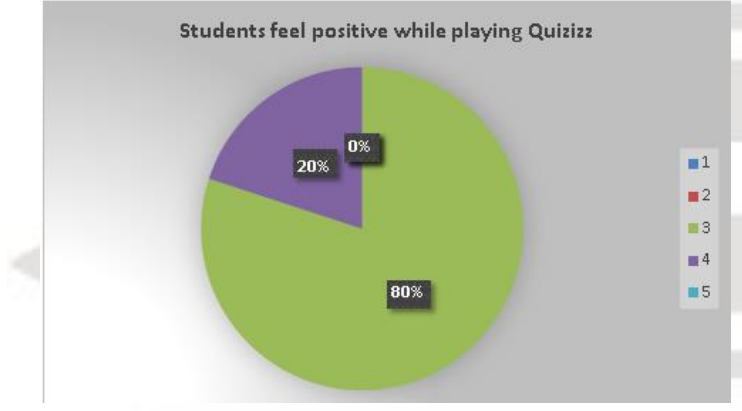

Figure 3. Students feel positive while playing Quizizz

This figure indicates that 20 percent agreed and the remaining 80 percent were neutral. This means that when students play Quizizz, they have a neutral feeling. According to the data, while playing Quizizz, some of the informants were leaning towards positive feelings.

Iya, saya merasakan dampak positif ya kayak jadinya saya harus bisa mengatur waktu dalam mengerjakean soal-soal yang ada, jadi ga buang buang waktu di satu soal aja. (Interview/S.1)

Iya, iya mempengarubi. (Interview/S.5)

Furthermore, according to the data presented above, the students' responses were neutral in terms of their eagerness to play Quizizz.

\section{Fostering Students' Collaboration and Competitiveness}

Based on the informants' statements, it is possible to conclude that they all enjoyed the collaboration and competition in the Quizizz session. This figure depicts the informants' attitudes toward their opinions.

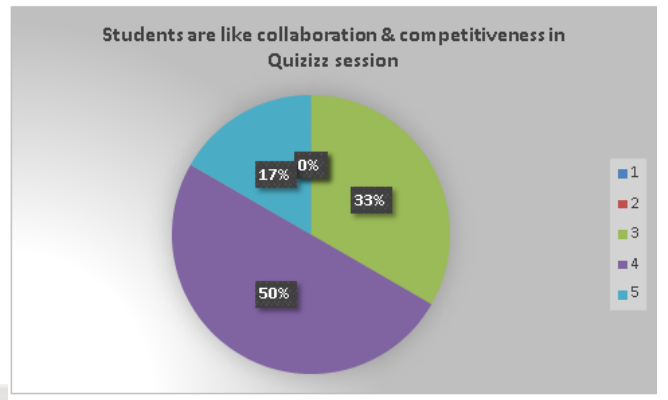

Figure 4. Fostering collaboration \& competitiveness in the Quizizz session

According to this figure, 17 percent of informants strongly agreed, 50 percent agreed, and 33 percent were neutral. This means that students prefer collaboration and competition during Quizizz sessions. Based on the data, it can be concluded that some of the informants agreed and had a positive attitude toward the Quizizz session's collaboration and competition.

Iya saya suka, karena itu yang membuat saya lebih tertantang gitu, jadi kayak saya itu mau jawab cepet tapi benar. (Interview/S.2)

In the Quizizz session, most students agreed that they enjoy collaboration and competition. Those who were neutral were inclined to like the collaboration and competitiveness in the Quizizz session, as stated by one of the interviewees. $Y$ a, sedikit suka. (Interview/S.5)

\section{Facilitating Students' Eagerness for Learning}

Based on the informants' statements, it is possible to conclude that they were all neutral on the students' eagerness to learn via Quizizz. This figure depicts the informants' attitudes toward this question.

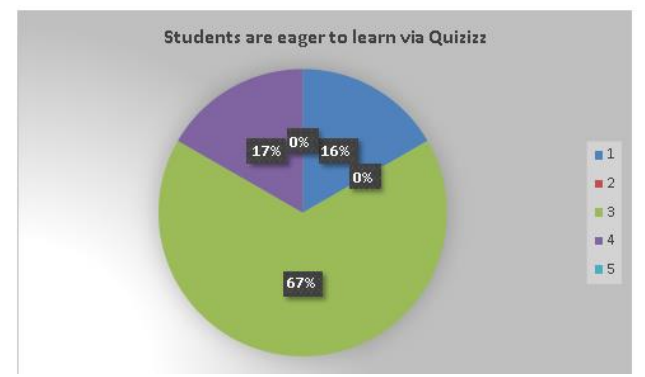

Figure 5. Students Eagerness to learn via Quizizz 
Based on the informants' statements, it is possible to conclude that they were all neutral regarding their eagerness to learn via Quizizz..

Netral sih pak, soalnya ada enaknya ada
enggaknya gitu, ada pengennya ada
enggaknya gitu, soalnya ada sisi buruk
ada sisi baiknya juga, (Interview/S.4)

Furthermore, several students stated that they agree and are neutral. They felt that using Quizizz was appropriate in several lessons that could motivate them to complete their assignments. However, several students disagreed on this point because they did not like the timing while doing Quizizz.

Enggak pak, karena kalau dapat soal yang susah kan butub waktu untuk mikir, kalau di Quizizz kan waktunya sangat cepat. Jadi takunya itu nggak nutuk gitu pak. (Interview/S.6)

\section{Creating Energetic Classroom Atmosphere}

Based on the informants' statements, it is possible to conclude that all of them were neutral on the issue of Quizizz creating an energetic classroom environment. This figure depicts the informants' attitudes toward their opinions.

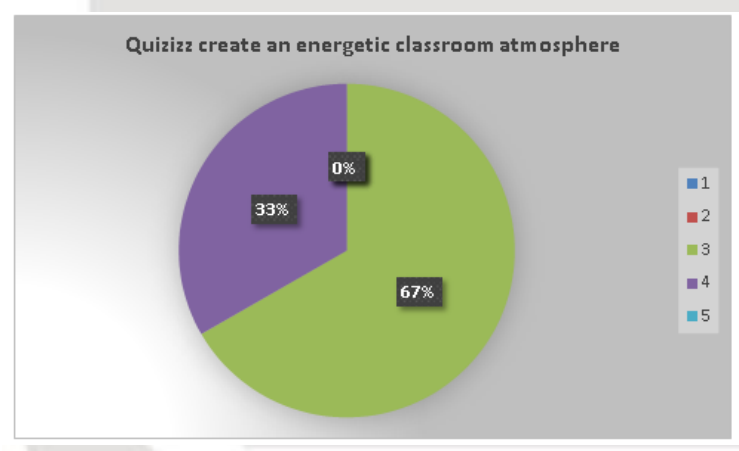

Figure 6. Quizizz create an energetic classroom atmosphere

This figure indicated that 33 percent agreed and 67 percent were neutral. It means that students were ambivalent about Quizizz's ability to create an energetic classroom environment..

Iya, karena semua anak yang dikasib itu bersaing gitu buat dapet peringkat atas. (Interview/S.2)

Iya, karena kita itu kayak di ajarin berfikir dengan cepat. Biar gak males gitu. (Interview/S.6)
However, the students' all agreed that they felt an energizing atmosphere while playing Quizizz.

\section{The existence of background noise in Quizizz disturbs students' concentration}

Based on the informants' statements, it is possible to conclude that they all agree that the presence of the background noise in Quizizz interferes with the their concentration. This figure depicts the informants' attitudes toward this question.

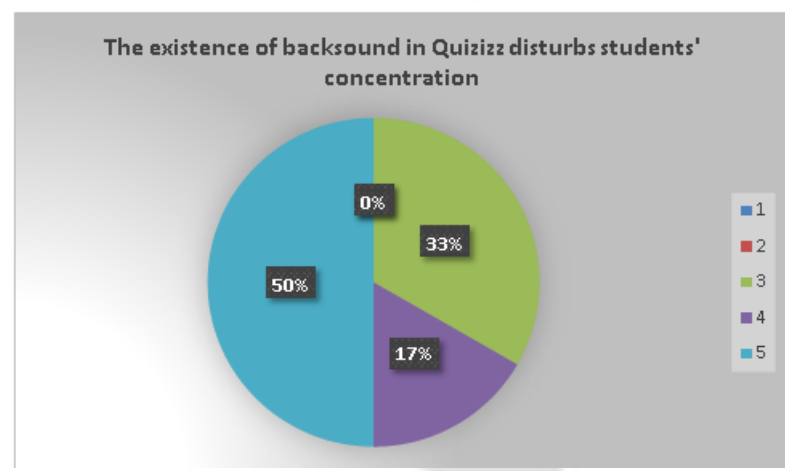

Figure 7. The existence of back sound in Quizizz disturbs students concentration

This figure reveals that 50 percent of informants strongly agreed, 17 percent agreed, and 33 percent were neutral. This means that the presence of background noise in Quizizz was noticed by the students. Based on that information, it is possible to conclude that some of the informants agreed that the existence of a background noise in Quizizz disrupts their concentration.

Backsoundnya mengganggu jadi membuat kita nggak. fokus. (Interview/S.5)

The presence of the this noise was intended to be beneficial, but students were irritated because they believed that when taking the quiz, they needed to be focused and not be distracted by the sound.

\section{Quizizz does not give any chance to cheat}

Based on the informants' statements, it is possible to conclude that they all agree that Quizizz does not allow for cheating. This figure depicts the informants' attitudes toward this issue. 


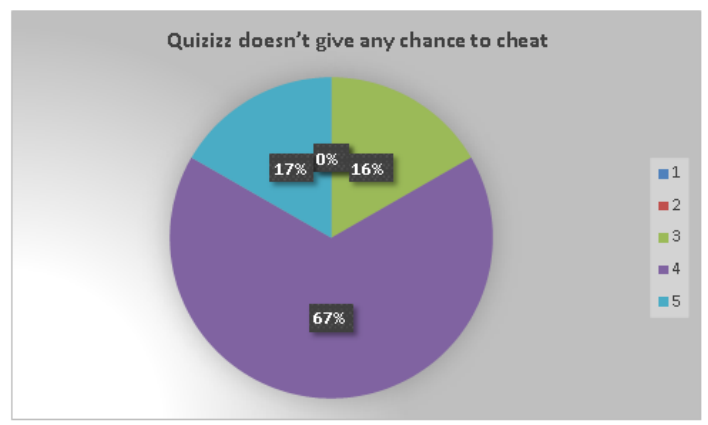

Figure 8. Quizizz doesn't give any chance to cheat

According to this figure, 17 percent of informants strongly agreed, 67 percent agreed, and 16 percent were neutral. It means that students believe that Quizizz does not allow them to cheat. Based on the data, it can be concluded that some of the informants agreed that Quizizz has the positive impact of not allow cheating.

Iya, soalnya kan kalau di Quizizz itu peluang contekannya itu kecil. Soalnya juga kan di ajak jadi gabisa diulangi lagi soalnya. Makannya itu kita bisa tau jawaban murni dari saya dan bukan dari contekan. (Interview/S.4)

Students stated that they found it difficult to cheat while taking the Quizizz test. This was because they had a very limited amount of time. It made them more focused on their test.

\section{Quizizz final leaderboard satisfies you}

Based on the informants' statements, it is possible to conclude that all of them agree that Quizizz's final leaderboard satisfies them. This figure depicts the informants' attitudes toward this issue.

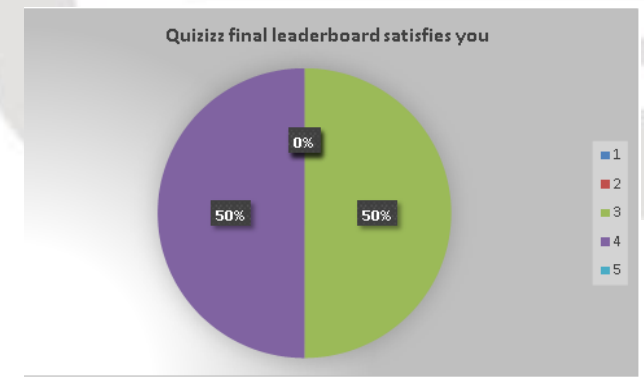

Figure 9. Quizizz final leaderboard satisfies you

This figure indicated that 50 percent agreed and 50 percent were neutral. This means that students were satisfied with Quizizz's final leaderboard. Based on the data, it can be concluded that some of the informants agreed and had a positive attitude toward the Quizizz leaderboard.

$Y$ a yang dari apa penomoran itu tadi yang ranking ranking itu tadi kalau yang lainnya sib biasa aja tapi lebih suka yang penomoran tadi jadi bisa tau oh anak ini itu meskipun biasa biasa aja tapi pemahaman soalnya luas jadi lebih mudah megerjakannya. (Interview/S.3)

The ranking feature on Quizizz boosted the students' confidence and enthusiasm. Some even claimed that by using Quizizz's ranking system, they can increase their positive competitiveness because they can learn about one another's abilities.

Yang membuat saya suka dan tertarik adalah rankingnya, jadi saya tau kemampuan teman saya seperti apa dan ketepatannya. (Interview/S.1)

\section{Offering some special challenging features}

Based on the statements of the informants, it is possible to conclude that they are all neutral on the subject of Quizizz's unique challenging features. This figure depicts the informants' attitudes toward this issue. 
previously mentioned. This feature is intended to improve grades. Where this feature appeared, several sessions were skipped by students. Students can use this feature to correct incorrect scores or answers. It is extremely beneficial to students. Quizizz's features, on the other hand, challenge students in each session when they work on questions. This feature uses a ranking system that can motivate students to answer all of the questions provided by Quizizz.

\section{Ada dua yang pertama itu ya yang ranking-ranking itu tadi, terus yang ke dua itu misal kita jawab soal itu salah terus kita kan juga tau jawaban yang benar itu apa. Jadi kalau misalkan untuk soal itu kita bisa tau jawabannya. Kalau di CBT kan gatau mana yang salah (Interview/S.3)}

\section{Revealing Students' Factual Competence}

Based on the informants' statements, it is possible to conclude that all of them agree that students believe Quizizz can reveal the students' true competence. This figure depicts the informants' attitudes toward this issue.

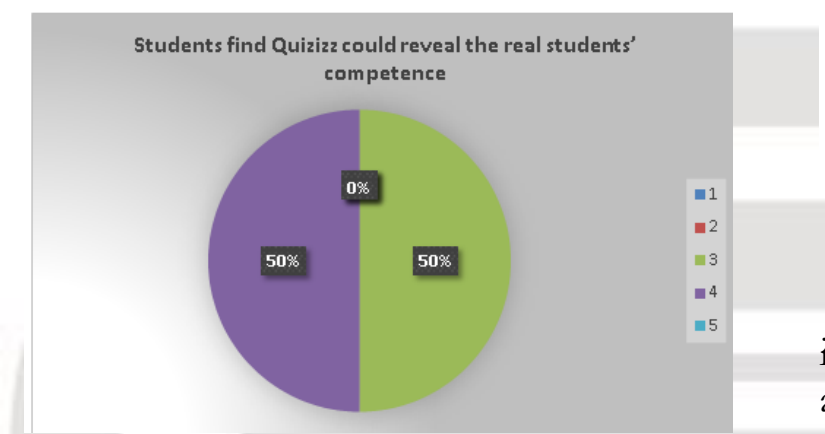

Figure 11. Students find Quizizz could reveal the real students' competence

This figure indicates that 50 percent agreed and 50 percent were neutral. This means that students believe that Quizizz is useful to reveal the true competence of students. Based on the data, it is possible to conclude that some of the informants agreed that Quizizz had a positive impact by revealing the true competence of students.

Jadi kayak saya tau kemampuan saya, ob di ranking segini kemampuanya. (Interview/S.2)

Soalnya kan kalo di quiziz itu peluang untuk contekannya dikit pak jadi soalnya kan kan diacak jadi gabisa diulangi lagi soalnya jadi mangkanya itu sudab jadi jawaban realnya saya jawaban realnya teman teman saya gitu pak, jadi nilainya juga dari situ, gak dari nilai contekan gitu. (Interview/S.4)

According to the students' statements, they believe that they can demonstrate their competence by working on the Quizizz questions. This is because of the limited time and few opportunities to cheat when taking the quiz.

\section{Students feel that Quizizz is familiar and simple to use}

Based on the informants' statements, it is possible to conclude that all of them agree that students find Quizizz to be familiar and simple to use. This figure depicts the informants' attitudes toward this issue.

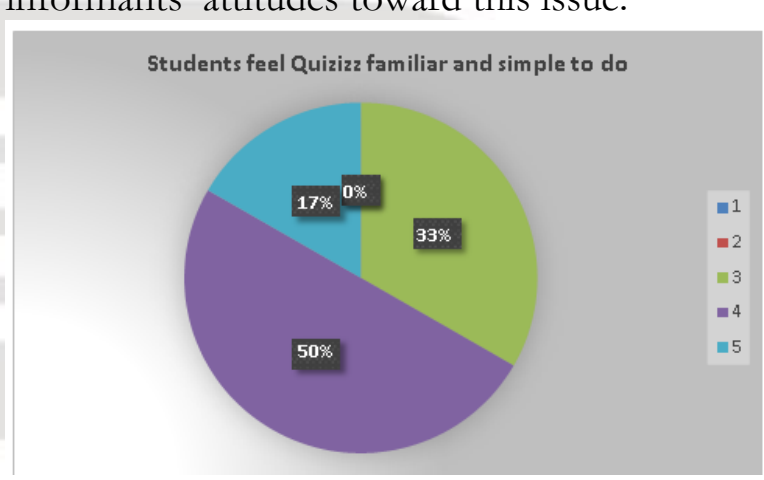

Figure 12. Students feel Quizizz familiar and simple to do

According to this figure, 17 percent of informants strongly agreed, 50 percent agreed, and 33 percent were neutral. This means that students found Quizizz to be familiar and simple to use. Based on the data, it can be concluded that all of the informants agreed that Quizizz is familiar and simple to use.

Tampilannya beda dengan yang lain. Itu yang membuat saya tertarik. (Interview/S.1) Cukup menarik. (Interview/S.2)

According to the interviewed students, the layout of the Quizizz platform was quite appealing and enticed them to use it. They also believe the platform is simple to use. 


\section{Providing an Attractive Display Design}

Based on the statements of the informants, it is possible to conclude that they all agree that Quizizz has an appealing display design. This figure depicts the informants' attitudes towards this issue.

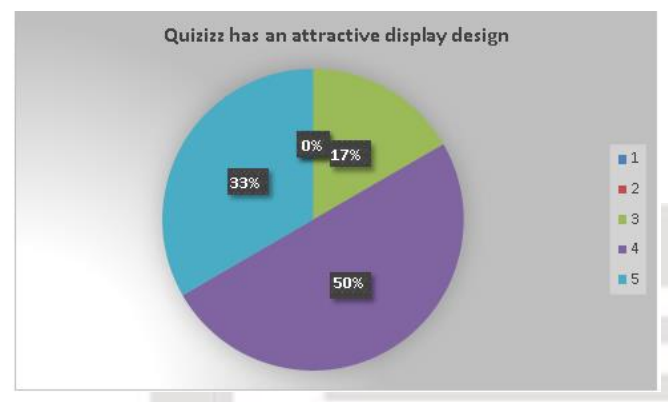

Figure 13. Quizizz has an attractive display design

According to this figure, 39 percent of respondents strongly agreed, 33 percent agreed, 26 percent were neutral, 2 percent disagreed, and 0 percent strongly disagreed. This means that students thought that Quizizz had an appealing display design. Based on the data, it can be concluded that all of the informants had a favorable opinion on Quizizz's display design.

Tampilannya beda dengan yang lain. Itu yang membuat saya tertarik. (Interview/S.1)

Students are interested in using and running the Quizizz platform because of their diverse perspectives. As a result, nearly all students agree that Quizizz has an appealing display design.

\section{Quizizz must be used in daily online quizzes}

Based on the informants' statements, it is possible to conclude that they all disagree on the point that the Quizizz must be used daily. This figure depicts the informants' attitudes toward this issue.

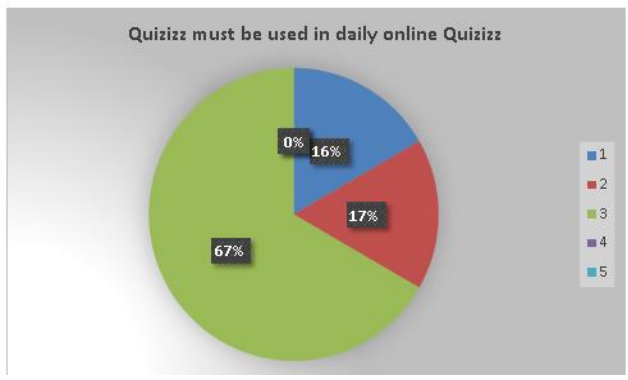

Figure 14. Quizizz must be used in daily online Quizizz
According to that figure, 67 percent were neutral, 17 percent disagreed, and 16 percent strongly disagreed. This means that students disagreed with the idea that Quizizz should be used daily. Based on this data, it can be concluded that the informants were divided on whether Quizizz should be used daily.

Iya, kan kalo kelas online kan lebib enak ngerjain pake hp daripada pake kertas. (Interview/S.1)

Some students agree that Quizizz should be used as a daily online evaluation because they believe that this can reduce excessive paper usage. In contrast to the above-mentioned statement by S.1, other students, on did not agree. They felt rushed when taking a quiz on Quizizz This is motivated by their lack of preparation and unpreparedness. because they did not read the material according to the assertion made by S.4.

Tidak, soalnya kan kalau pakai Quiziz: itu jawabnya jadi keburu buru gitu pak soalnya kan ada waktunya gitu pak, terus kalau selesainya lama poinnya juga dikurangi gitu pak. (Interview/S.4)

According to the findings of this study, students have a positive perception on the use of Quizizz as an online assessment tool. Positive perception is a wonderful gift that prepares one for involvement in the world, enduring difficulties, and focusing on things other than oneself ${ }^{21}$. It encourages the formation of relationships and the giving of oneself to others.

According to the data, there are several reasons why students had a positive perception on the use of Quizizz as an assessment platform in English classes. To begin, they all agreed that Quizizz was exciting, interesting, motivating, and entertaining. This was because the Quizizz platform differed from other platforms. Quizizz had an interactive display, which made it easy for students to use the platform. The students also had a good time assessing Quizizz. They said it was exciting that they

${ }^{21}$ Catherine Burns and others, 'Pediatric Primary Care 6th Edition', Elsevier, 2017. 
could compete with each other. They were also familiar with technology and have a good understanding of the subject. Students found it simple to use the technology; this allowed them to work more efficiently. This is consistent with the finding of the research undertaken by Balakrishan, et $\mathrm{al}^{22}$ who stated that students will work more efficiently if they are familiar with technology and understand the material. As a result, students must have a basic understanding of web technologies to complete online Quizizz assessments.

The second reason why students were interested in using online assessment was that it reduced the use of paper while taking the test. Furthermore, the presentation and features of Quizizz were organized attractively and interactively. This is line with research undertaken by Dinda Firly Amalia ${ }^{23}$, who stated that Quizizz has an appealing and intriguing display. A paper evaluation, on the other hand, was too monotonous. As a result, students have a good time taking online quizzes on Quizizz.

It has already been confirmed by Čandrlić et $\mathrm{al}^{24}$ in their study that students prefer online assessments to paper assessments. As a result, the presence of interesting features in Quizizz may pique their interest in taking online tests. The third reason students prefer Quizizz for assessment is that it does not allow for cheating. The students were able to focus on the test by using Quizizz. This is because they must concentrate on their evaluation without consulting or cheating their friends. Quizizz's limited-time

22 Vimala Balakrishnan and Chin Lay Gan, 'Students' Learning Styles and Their Effects on the Use of Social Media Technology for Learning', Telematics and Informatics, $\quad 33.3 \quad$ (2016), $\quad 808-21$ $<$ https://doi.org/10.1016/j.tele.2015.12.004>.

${ }^{23}$ Dinda Firly Amalia, 'Quizizz Website as an Online Assessment for English Teaching and Learning: Students' Perspectives', Jo-ELT Journal of English Language Teaching) Fakultas Pendidikan Bahasa \& Seni Prodi Pendidikan Babasa Inggris IKIP, 7.1 (2020), 1 $<$ https://doi.org/10.33394/jo-elt.v7i1.2638>.

${ }^{24}$ Sanja Candrlić, Martina Ašenbrener Katić, and Martina Holenko Dlab, 'Online vs. Paper-Based Testing: A Comparison of Test Results', 2014 37th International Convention on Information and Communication Technology, Electronics and Microelectronics, MIPRO 2014 Proceedings, May, 2014, 657-62 <https://doi.org/10.1109/MIPRO.2014.6859649>. feature can help to reduce the likelihood of cheating. This is consistent with ${ }^{25}$ the statement that students cannot cheat during a Quizizz test. In this case, one of Quizizz's strengths is that it has an appealing design that can reveal the students' competence.

However, in addition to the positive perception of the use of Quizizz as an assessment platform in teaching English, some students expressed a negative perception of the use of Quizizz as an assessment tool.

According to the data, one of the negative perceptions of Quizizz was the presence of background music on the platform. The students were irritated while taking the test. Aside from the troubling case of using Quizizz, some students were concerned about the limited time they had when they took tests. This is because some students still needed to think more when given a difficult test. However, they only had a limited amount of time to complete the test on Quizizz. Furthermore, they will lose a point if they do not finish. As a result, they must concentrate during the assessment run.

\section{Conclusion}

Based on the findings discussed about students' perceptions of the use of Quizizz as an assessment platform in teaching English, there are two distinct perceptions reported. Generally, the students reported positive perception on the use of Quizizz as assessment platform. The students enjoyed Quizizz and thought it was exciting, interesting, motivating, and enjoyable. Furthermore, it enhanced students' eagerness to play it. Moreover, Quizizz has an interactive display, which made it simple for students to use the platform. However, several students reported negative perception on the use of Quizizz as assessment platform in teaching English. One of the major reasons is that the presence of background music. They reported that they were irritated due to this background noise.

Several suggestions or recommendations can be made to both the

25 Amalia. 
English teacher and the next researcher. The use of online assessments in Quizizz, according to this study, can be an effective technique for identifying students' development. According to the findings of this study, students have both positive and negative feelings about using Quizizz for online assessment. They also hope that other teachers will be able to use Quizizz to assess the development of their students. For future researchers, as the quality of students is improving daily, and it will inevitably become more difficult. They can conduct similar research with a different focus; there are many LMS available to access and use. Future researchers can supplement their study with additional research instruments or add another research question to their study.

\section{References}

\section{Journal}

Amalia, Dinda Firly, 'Quizizz Website as an Online Assessment for English Teaching and Learning: Students' Perspectives', Jo-ELT Journal of English Language Teaching) Fakultas Pendidikan Babasa \& Seni Prodi Pendidikan Bahasa Inggris IKIP, $7.1 \quad$ (2020), 1 <https://doi.org/10.33394/joelt.v7i1.2638>

Balakrishnan, Vimala, and Chin Lay Gan, 'Students' Learning Styles and Their Effects on the Use of Social Media Technology for Learning', Telematics and Informatics, 33.3 (2016), 808-21 <https://doi.org/10.1016/j.tele.2015.12 $.004>$

Basuki, Yudi, and Yeni Hidayati, 'Kahoot! Or Quizizz: The Students' Perspectives', January, 2019 <https://doi.org/10.4108/eai.27-42019.2285331>

Benson, Jeryl D., Kimberly A. Szucs, and Meredith Taylor, 'Student Response Systems and Learning: Perceptions of the Student', Occupational Therapy in Health Care, 30.4 (2016), 406-14 <https://doi.org/10.1080/07380577.20 16.1222644>

Burns, Catherine, Ardys M. Dunn, Margaret A. Brandy, Nancy Barber Starr, Catherine G. Blosser, and Dawn Lee Garzon, 'Pediatric Primary Care 6th Edition', Elsevier, 2017

Čandrlić, Sanja, Martina Ašenbrener Katić, and Martina Holenko Dlab, 'Online vs. Paper-Based Testing: A Comparison of Test Results', 2014 37th International Convention on Information and Communication Technology, Electronics and Microelectronics, MIPRO 2014 - Proceedings, May, 2014, 657-62 <https://doi.org/10.1109/MIPRO.201 4.6859649>

Fakhruddin, Afief, and Eka Nurhidayat, 'Students' Perception on Quizziz As Game Based Learning in Learning Grammar in Writen Discourse', Wiralodra English Journal, 4.2 (2020), 28 38

$<$ https://doi.org/10.31943/wej.v4i2.10 $1>$

Harefa, Nelius, Marudut Sinaga, and Saronom Silaban, 'Students Perception and Interest on Chemistry: Learning Evaluation Integrated Quizziz Media', Jurnal Pendidikan Kimia, 12.3 (2020), 143 50

$<$ https://doi.org/10.24114/jpkim.v12i3 .21163>

Hidayati, Prema Hapsari, Ratih Natasha, Shofiyah Latief, Nasruddin $\mathrm{Ma}$, and Syarifuddin Wahid, 'Implementation of Quizziz as a Pretest and Post-Test to Evaluate the Effectiveness of Small Group Learning', 567.Icme (2021), 15660

Irwansyah, R, and M Izzati, 'Implementing Quizizz as Game Based Learning and Assessment in the English Classroom', TEFLA Journal (Teaching English as ..., $3.1 \quad$ (2021), 13-18 $<$ https://journal.umbjm.ac.id/index.ph $\mathrm{p} /$ TEFLA/article/view/756>

Junior, João Batista Bottentuit, 'Assessment for Learning With Mobile Apps: Exploring the Potential of Quizizz in the Educational Context', International 
Journal of Development Research, 10.1 (2020), 33366-71

Kats, Yefim, Learning Management System Technologies and Software Solutions for Online Teaching: Tools and Applications, Learning Management System Technologies and Software Solutions for Online Teaching: Tools and Applications, 2010 <https://doi.org/10.4018/978-1-61520853-1>

McNeill, Patrick, and Steve Chapman, Research Methods: Third Edition, Research Methods: Third Edition, 2005 <https://doi.org/10.4324/97802034630 $00>$

Meng, Cheng Kin, Junita Shariza Binti Mohd Nasir, Tan Ming Ming, and Koo Ah Choo, 'A Gamified Classroom with Technical and Vocational Education and Training ( TVET ) Students Using Quizziz', International Journal of Education, Islamic Studies and Social Sciences Research (IJEISR), $4.1 \quad$ (2019), 1-6 $<$ http://ijeisr.net/Journal/Vol-4-No-1Isu-02.pdf $>$

Mohamad, Maslawati, Fatin Kamilia Mohd Arif, Bity Salwana Alias, and Melor Md Yunus, 'Online Game-Based Formative Assessment: Distant Learners Post Graduate Students' Challenges towards Quizizz', International Journal of Scientific and Technology Research, 9.4 (2020), 9941000

<https://doi.org/10.13140/RG.2.2.174 $16.75528>$

Mohd Jalani, Nurfarahin Adawiah Binti, and Harwati Binti Hashim, 'Quizziz: ESL Students' Perceptions in Rural School', International Journal of Scientific and Research Publications (IJSRP), 10.3 (2020), p9904 <https://doi.org/10.29322/ijsrp.10.03.2 020.p9904>

No Title 学姐单词

Nojen, Emily A., 'The Effectiveness Of Interactive Learning Based On Quizziz Applications Among Students Of Tourism And Hospitality Marketing', Jurnal Asian Pendidikan, 1 (2021), 22-27

Orhan Göksün, Derya, and Gülden Gürsoy, 'Comparing Success and Engagement in Gamified Learning Experiences via
Kahoot and Quizizz', Computers and Education, 135.March (2019), 15-29 $<$ https://doi.org/10.1016/j.compedu.2 019.02.015>

Ozden, M., Ismail Erturk, and Refik Sanli, 'Students' Perceptions of Online Assessment: A Case Study.', International Journal of E-Learning \& Distance Education, 19.2 (2004), 77-92

Permana, Pepen, and Irma Permatawati, 'Using Quizizz as a Formative Assessment Tool in German Classrooms', 424.Icollite 2019 (2020), 155-59

<https://doi.org/10.2991/assehr.k.200 325.073>

Pradnyadewi, Diah Ayu Manik, and Putu Enik Kristiani, 'Use of Quizizz In Improving Students' Reading Skill', The Art of Teaching English as a Foreign Language, 1.2 (2021), <https://doi.org/10.36663/tatefl.v1i2.9 3>

Rahman, Rahmania, Erric Kondoy, and Awaluddin Hasrin, 'Penggunaan Aplikasi Quizziz Sebagai Media Pemberian Kuis Dalam Meningkatkan Motivasi Belajar Mahasiswa', JISIP (Jurnal Ilmu Sosial Dan Pendidikan), 4.3 (2020), 60-66 <https://doi.org/10.36312/jisip.v4i3.11 61>

Roysa, Mila, and Anisa Hartani, 'Aplikasi Daring Quizziz Sebagai Solusi Pembelajaran Menyenangkan Di Masa Pandemi', Lentera: Jurnal Ilmiah Kependidikan, 13.2 (2020), 315-26 <https://doi.org/10.52217/lentera.v13i $2.650>$

Syah, Rizqon H, 'Dampak Covid-19 Pada Pendidikan Di Indonesia: Sekolah, Keterampilan, Dan Proses Pembelajaran', SALAM: Jurnal Sosial Dan Budaya Syar-I, $7.5 \quad$ (2020) $<$ https://doi.org/10.15408/sjsbs.v7i5.1 5314>

Ubaidah, Nila, Imam Kusmaryono, and Anggar Titis Prayitno, 'Pendekatan Steam Berbasis Quizizz Terhadap Kemampuan Pemecahan Masalah', Konferensi Nasional Penelitian Matematika 
Dan Pembelajarannya(KNPMP) V, 2020, 351-62 <https://publikasiilmiah.ums.ac.id/xml ui/bitstream/handle/11617/12224/ME 27.pdf?sequence $=1 \&$ is Allowed $=\mathrm{y}>$ 